\title{
A geometric morphometric analysis of hominin upper first molar shape
}

\author{
A. Gómez-Robles a,*, M. Martinón-Torres a , J.M. Bermúdez de Castro a , A. Margvelashvili a ${ }^{\text {ab }}$, \\ M. Bastir ${ }^{\text {c,d }}$, J.L. Arsuaga ${ }^{\mathrm{e}}$, A. Pérez-Pérez ${ }^{\mathrm{f}}$, F. Estebaranz ${ }^{\mathrm{f}}$, L.M. Martínez ${ }^{\mathrm{f}}$ \\ ${ }^{a}$ Centro Nacional de Investigación sobre Evolución Humana (CENIEH), Avda. de la Paz, 28, 09006 Burgos, Spain \\ ${ }^{\mathrm{b}}$ Georgian National Museum, Purtseladze, 3, 0105 Tbilisi, Georgia \\ ' Department of Palaeobiology, Museo Nacional de Ciencias Naturales, CSIC. C/José Gutiérrez Abascal 2, 28006 Madrid, Spain \\ 'Hull York Medical School, The University of York, Heslington, York YO10 5DD, United Kingdom

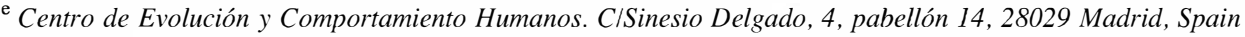 \\ ${ }^{\mathrm{f}}$ Department on Animal Biology, Section of Anthropology, University of Barcelona, Av. Diagonal 645, 08028 Barcelona, Spain
}

\begin{abstract}
Recent studies have revealed interesting differences in upper first molar morphology across the hominin fossil record, particularly significant between $H$. sapiens and $H$. neanderthalensis. Usually these analyses have been performed by means of classic morphometric methods, including the measurement of relative cusp areas or the angles defined between cusps. Although these studies have provided valuable information for the morphological characterization of some hominin species, we believe that the analysis of this particular tooth could be more conclusive for taxonomic assignment. In this study, we have applied geometric morphometric methods to explore the morphological variability of the upper first molar $\left(\mathrm{M}^{1}\right)$ across the human fossil record. Our emphasis focuses on the study of the phenetic relationships among the European middle Pleistocene populations (designated as $H$. heidelbergensis) with $H$. neanderthalensis and $H$. sapiens, but the inclusion of Australopithecus and early Homo specimens has helped us to assess the polarity of the observed traits. H. neanderthalensis presents a unique morphology characterized by a relatively distal displacement of the lingual cusps and protrusion in the external outline of a large and bulging hypocone. This morphology can be found in a less pronounced degree in the European early and middle Pleistocene populations, and reaches its maximum expression with the $H$. neanderthalensis lineage. In contrast, modern humans retain the primitive morphology with a square occlusal polygon associated with a round external outline.
\end{abstract}

Keywords: Neandertals; Dental anthropology; Geometric morphometrics; Maxillary molars

\section{Introduction}

Teeth are a valuable and durable source of information for anthropological research based, on the one hand, on their abundance and excellent preservation in the fossil record (e.g., Butler, 1963; Larsen and Kelley, 1991). The scope of dental anthropology ranges from ecological studies (e.g., Molnar, 1971; Hillson, 1986; Lalueza and Pérez-Pérez, 1993; PérezPérez et al., 2003; Lozano et al., 2004) to the characterization of species (e.g., Weidenreich, 1937; Le Gros Clark, 1950; Tobias, 1991) and the reconstruction of their relationships (e.g., Irish, 1997, 1998; Bailey, 2000, 2002; Irish and Guatelli-Steinberg, 2003). Moreover, teeth do not suffer remodellation in response to environmental stresses as other skeletal parts do (Dahlberg, 1971; Larsen and Kelley, 1991; Thomason, 1997), so once they are formed, their morphology is only affected by attrition or decay. Therefore, teeth are excellent and stable markers for affinity studies within and among populations (Turner, 1969) and, thus, for the study of human ancestors (Irish, 1993). Among other things, dental anthropology investigates the taxonomic utility of teeth, searching for morphometric traits that may be useful in characterizing hominin groups. 
The origin of $H$. sapiens, our relationship with $H$. neanderthalensis, and the identification of $\bullet$ last common ancestor is

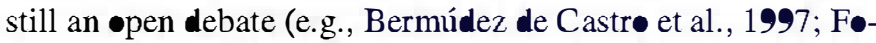
ley and Lahr, 1997; Lahr and F•ley, 1998; Rightmire, 1998; Stringer and Hublin, 1999; Stringer, 2002). Thus, it is necessary to search for morphølogical traits that establish the similarities and differences among the groups under discussion. We contribute to this debate by comparing modern humans and Neandertals with the crucial inclusion of the large dental sample from Atapuerca-Sima de los Huesos site that are representative of $H$. heidelbergensis and considered direct ancestors of $H$. neanderthalensis (Arsuaga et al., 1997), and from the Atapuerca-TD6 sample, the only dental remains recovered, s• far, from the Eurøpean early Pleistøcene (Bermúdez de Castr• et al., 1997). In addition, we alsø include a large sample of teeth assigned to several species of the genera Australopi-

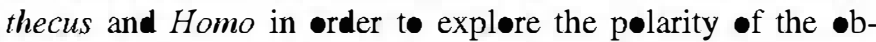
served morphølogies.

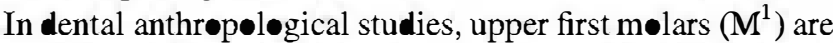
pøtentially useful før tax॰n๑mic assignment of isølated human remains (e.g., Wood and Engleman, 1988; Tattersall and Schwartz, 1999; Bailey, 2004) and are even distinct among different modern human populations (Morris, 1986). Moreover, $\mathbf{M}^{1}$ morphølogy has been shown to be distinctive in $H$. neanderthalensis (Bailey, 2004). These conclusions usually come from personal observation and classic metric studies using linear measurements of the crown (Morris, 1986; Wood and Engleman, 1988), cusps angles (Morris, 1986; Bailey, 2004), relative cusp areas (Wood and Engleman, 1988; Bailey, 2004), and occlusal polygon areas (defined by lines connecting cusp apices; Morris, 1986; Bailey, 2004). In addition, $\mathrm{M}^{1}$ dis-

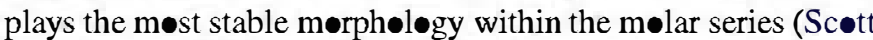
and Turner, 1997), which undoubtedly makes it easier t• identify høm॰logøus landmarks despite variation amøng species.

The Arizøna State University Dental Anthrøp॰løgy System (ASUDAS; Turner et al., 1991) is one of the standards devel-ped to assess modern human dental variability and it has been alsø applied to $\bullet$ ther fossil hominin species with moderate success (e.g., Irish, 1997, 1998; Bailey, 2000, 2002; Irish and Guatelli-Steinberg, 2003). However, this system fails to cover the complete range of dental variation in the hominin fossil record (Bailey, 2002, 2004; Hluskø, 2004; Martinón-Tørres, 2006), particularly in the case of the upper first molar. Furthermøre, classic morphømeric studies have als• revealed certain limitations for characterizing the dental variability of søme pøpulations (e.g., Gøose, 1963; Hillsøn et al., 2005; Støjan॰wski, 2006), motivating the search for alternative methods with different degrees of success (Biggerstaff, 1969; Morris, 1986; Mayhall, 2000; Bailey, 2004; Hillsøn et al., 2005; Støjanowski, 2006).

In relation to this matter, geometric morphometric techniques have been proven to be effective tools for measuring shape variation, allowing powerful statistical comparisons (Røhlf and Marcus, 1993). Therefore, their application to dental studies might advance our knowledge of dental morphølogical variability and its ev॰lutionary significance. The possibility finding apømorphic traits for characterizing paleospecies
(Wølpøff, 1971; Bytnar et al., 1994; Bailey, 2000, 2002, 2004; Bailey and Lynch, 2005) makes it worthwhile t॰ expløre alternative methodølogies. In the dental field, geømetric morph -

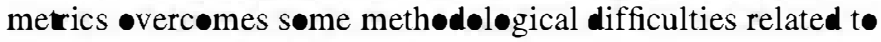
absølute tøoth orientation within the jaw and helps us tø understand outline shape variation with respect to biøløgically meaningful structures, such as the spatial configuration of cusps, and their relationship tø overall size (Martinon-Tørres et al., 2006).

The aim of our study is to evaluate the phenetic relationships amøng Eurøpean middle Pleistocene populations, $H$. neanderthalensis and $H$. sapiens, exploring the differences in $\mathbf{M}^{1}$

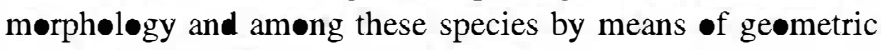
mørphømetrics. Previøus studies lacked samples large enøugh to ascertain primitive versus derived nature of the $\mathbf{M}^{1}$ shape variation (Bailey, 2002, 2004). The inclusion of a sample of early Homo and Australopithecus in the comparison will

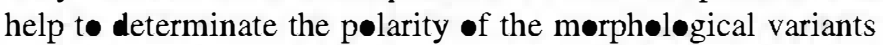
and whether these differences have any utility in the tax-n॰mic assignment of specimens.

Materials and methods

Materials and photographic methods

We performed a geømetric morphømetric analysis on a sample of $105 \mathrm{M}^{1} \mathrm{~s}$ from several hominin species with special emphasis on $H$. heidelbergensis, $H$. neanderthalensis and $H$. sapiens. The sample included (Table 1): Australopithecus anamensis $(n=2), A$. arensis $(n=6), A$ africanus $(n=10)$, Homo habilis sensu lato $(n=10), H$. ergaster $(n=4), H$. erectus $(n=5), H$. georgicus $(n=2), H$. antecessor $(n=3), H$. heidelbergensis $(n=16), H$. neanderthalensis $(n=14)$, and $H$. sapiens $(n=32)$.

The inclusion of Australopithecus and other Pliøcene and Pleistocene Homo specimens in the comparisøn helped us to assess the phylogenetic significance of the observed differences. Australopithecus species were analyzed separately. For comparative purposes, specimens usually ascribed to $H$. habilis and $H$. rudolfensis, as well as some African Pliecene specimens without consensus in their tax॰n-mical assignment, were grouped as $H$. habilis s.l. The African specimens attributed by some authors to $H$. erectus sensu lato (Walker and Leakey, 1993) were analyzed as $H$. ergaster (Groves and Mazák, 1975), leaving the denomination $H$. erectus (Dubøis, 1894) for the Asian specimens (Andrews, 1984; Stringer, 1984; Wøod, 1984). A North African early middle Pleistocene specimen assigned to $H$. mauritanicus by Hublin (2001) was included in $H$. ergaster. We used the denomination $H$. georgicus for the Dmanisi hominins (Gabunia et al., 2002) and $H$. antecessor (Bermúdez de Castrø et al., 1997) før the Eurøpean early Pleistocene specimens from Atapuerca-TD6. Hominins from the European middle Pleistocene were grouped as $H$. heidelbergensis, and the $H$. neanderthalensis taxon comprised classic late Pleistocene European Neandertals. Finally, the $H$. sapiens sample included a medieval collection from the San Nicœás site (Murcia, Spain; Gønzález, 1990) and specimens frøm several Eurøpean Upper Paleølithic sites. 
Table 1

List of the specimens included in this analysis

\begin{tabular}{|c|c|}
\hline Australopithecus anensis $(n=2)$ & ER31200; ER31400 (casts) \\
\hline Australopithecus farensis ( $n=6)$ & AL200; AL486; LH3H; LH6; LH17; LH21 (casts) \\
\hline Australopithecus africanus $(n=1 \mathbf{0})$ & MLD6; TM1511; STS1; STS8; STS21; STS52; STS56; STS57; STW151; STW183 (casts) \\
\hline Homo habilis s.l. $(n=10)$ & SE255; ER81; ER1590; ER1813; OH6; OH13; OH21; OH39, OH41; OH44 (casts) \\
\hline Homo georgicus $(n=2)$ & 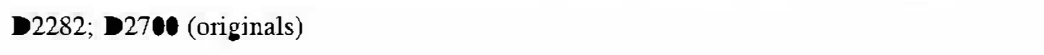 \\
\hline Homo ergaster $(n=4)$ & SK27; SKX268; WT15000; Rabat (casts) \\
\hline Homo erectus $(n=5)$ & Sangiran 7-3; 7-9; 7-1 ; 7-37; 7-4@ (casts) \\
\hline Homo antecessor $(n=3)$ & ATD6-18; ATD6-69; ATD6-1 3 (originals) \\
\hline Homo heidelbergensis $(n=16)$ & $\begin{array}{l}\text { Arago 9; } 54 \text { (casts) } \\
\text { Sima de los Huesos: AT-1100; AT-16; } \\
\text { AT-196; AT-2 } 1 \text {; AT-2 } 1 \text {; AT-26; AT-3177; } \\
\text { AT-587; AT-767; AT-772; AT-812 (originals) } \\
\text { Pontnewydd: 4; } 12 \text { (casts) } \\
\text { Steinheim (cast) }\end{array}$ \\
\hline Homo neandertalensis $(n=14)$ & $\begin{array}{l}\text { Krapina: MxA; MxB; } 100 ; 134 ; 136 ; 166 ; 171 ; \text { (casts) } \\
\text { Pinilla del Valle: PIN1 (original) } \\
\text { Kulna: Kulna } 1 \text { (cast) } \\
\text { Le Moustier: Le Moustier } 1 \text { (cast) } \\
\text { Saint Cesaire: SC; SC1 (casts) } \\
\text { Sidrón: SDR } 12 \text { (cast) } \\
\text { Tabun: TB1 (C1) (cast) }\end{array}$ \\
\hline Homo sapiens $(n=32)$ & $\begin{array}{l}\text { Mladec: Mladec } 1 \text { (cast) } \\
\text { Jebel Iroud (cast) } \\
\text { Alinonda (cast) } \\
\text { Trou Magritte (cast) } \\
\text { Abri Pataud: Pataud } 1 \text { (cast) } \\
\text { Dolni Vestonice 13; } 14 ; 15 \text { (originals) } \\
\text { Medieval modern human collection from Universidad Autónoma de Madrid (originals) }\end{array}$ \\
\hline
\end{tabular}

Environmental stresses may influence the development of the genetic pattern in both antimeres resulting in fluctuating asymmetry (Waddington, 1957). However, asymmetry in den-

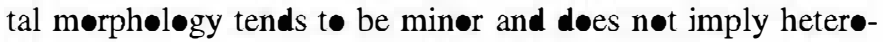
zygosity (Trinkaus, 1978; Scott and Turner, 1997). We randomly chose the left antimere for these analyses. In order to maximize sample sizes, when the left tooth was absent or when the landmarks were less clear, the right tooth was mirrør-imaged with Adøbe Phøt॰shøp ${ }^{\bullet}$. Teeth with severe attritional wear were not included.

We used standardized occlusal surface pictures of the $\mathbf{M}^{1}$. Images were taken with a Nikon ${ }^{\bullet} \mathrm{D} 1 \mathrm{H}$ digital camera fitted with an AF Micr-Nikø 105 mm, f/2.8D. The camera was at-

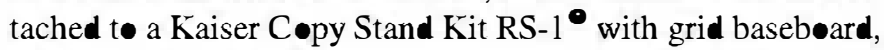
column, and adjustable camera arm, ensuring that the lens was parallel to the baseboard and the cementoenamel junction (CEJ). For maximum depth of field, we used an aperture of $\mathrm{f} / 32$. The magnification rati was adjusted to $1: 1$, and a scale was included and placed parallel to, and at the same distance from the lens as, the occlusal plane.

Some authors have pointed to some problems that may derive from working on $2 \mathrm{D}$ projections of $3 \mathrm{D} \bullet b j e c t s$, such as the possible distortion of the original size and shape of the structures (Frieß, 2003) and the orientation of the photographed elements (Gharaibeh, 2005). Although, ideally, this type of study should be performed directly on 3D structures, there are an important number of dental morphøløgical studies that have been successfully performed on 2D images of the teeth (Bailey, 2004; Bailey and Lynch, 2005; Martinón-Torres et al., 2006; Pérez et al., 2006, amøng the most recent).

\section{Geometric morphometric methods}

Geømetric morphømetrics capture the spatial aspects of mørphøløgical variation of biøløgical structures. Shape variation in morphological structures is captured by configurations -f landmarks, which are points of correspondence between different objects that match between and within populations (Bøokstein, 1991; O'Higgins, 2000; Zelditch et al., 2004). Landmarks have both coordinates and a biøløical significance (Bøokstein, 1991). Generalized Procrustes superimp•sition (GPA; Sneath, 1967; Røhlf and Slice, 1990; Dryden and Mardia, 1998) produces a common consensus or mean configuration of the studied sample by iteratively minimizing the distances between corresponding landmarks using leastsquares methods, after translation, rotation, and scaling of the configurations. The results of the generalized Procrustes superimposition are scatters of corresponding landmarks (Procrustes shape coordinates) around their means. The shape -f a Procrustes registered landmark configuration is defined by the entirety of its residual coordinates (Zelditch et al., 2004). 
Thin-plate spline (TPS) provides another representation of the shape differences between tw $\bullet$ objects by a deformation -f the first specimen int the secønd one. The total def $\bullet$ rmation between tw particular specimens or between a specimen and the consensus configuration can be partitioned int a uniform and a non-umiform component. The uniform component affects the whole configuration of landmarks in the same manner such as is the case with shearing. The non-uniform component requires bending energy and contributes to the deformation of specific regions of the structure (Bøokstein, 1991). The properties of this bending energy can be used to derive a set of powerful shape descriptors, the partial warps plus the uniform component (Bøokstein, 1989, 1991, 1996a; Røhlf, 1996).

Finally, relative warps analysis (Bøokstein, 1991) corresponds to a principal components analysis of the partial warp scores and illustrates the main patterns of morphøløgical variation. Given its similarity t• principal components analysis, relative warps are a useful tøol for exploring variation, and they serve to reduce the total variation to a smaller number -f independent dimensions (Frieß, 2003). Typically, the first few components (or relative warps) summarize most of the variation of a sample (Frieß, 2003). The relative warps analysis was perførmed using TpsRelw søftware (Røhlf, 1998a).

More detailed information about this method and its applications can be found in other texts (e.g., Bøokstein, 1989,

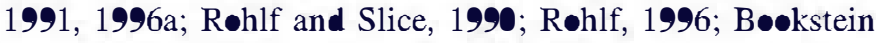
et al., 1999, 2003: Bastir et al., 2004, 2005).

\section{Canonical variates analysis}

T• better understand the variability of our sample we performed a canonical variates analysis (CVA), appropriate to

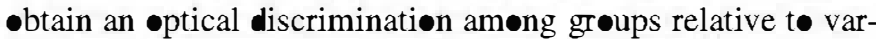
iation within groups, in as much as the individuals can be organized in mutually exclusive groups (Zelditch et al., 2004). This type of analysis is highly recommended in studies where the variation among individuals is high, since it maximizes intergrøup variability relative tø intragrøup variability (Albrecht, 1980 ).

In $\bullet$ rder to have a significant representation of the intragrøup variability, the CVA was only performed for those grøups with a sample size greater than ten (i.e., A. africanus, $H$. habilis s.l., $H$. heidelbergensis, $H$. neanderthalensis, and $H$. sapiens). The CVA was performed employing a generalization of Fisher's linear discriminant function, t॰ determinate a linear combination from the original variables which maximizes intergroup variability (Mardia et al., 1979). Since the CVA describes differences amøng groups, its results and interpretations may differ frøm those $\bullet$ btained with the PCA. In addition, CVA implies a rescaling and reorientation of the axis maximizing intergroup variance relative to intragroup variance (Zelditch et al., 2004). We employed the TpsRegr søftware (R॰hlf, 1998b) f॰r multivariate regression of shape data on $\mathrm{CV}$ scores to visualize the shape ass ciate to a given canonical axis.

From the CVA, an assignment test was performed. With this test, each individual is assigned to one of the pre- established grøups, calculating the probability of the Mahalanøbis distance between each individual and its group mean being lower than the expected distance under the null hyp thesis of random variation (Zelditch et al., 2004). This type of test is employed to evaluate the utility of the axis derived from the CVA, to discriminate and determine the affinity of the groups established a priori (Nolte and Sheets, 2005).

\section{Landmarks and semilandmarks}

As we mentioned abøve, landmarks are pøints of biøløical and geometric correspondence among specimens (Zelditch et al., 2004). In 2D space they have two clear cœordinates. Landmarks should be chosen according to their utility in assessing

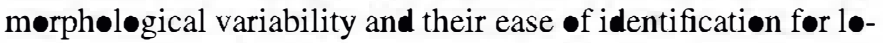
cation and reløcation without error (Zelditch et al., 2004). In this study, four landmarks were chøsen $\bullet$ the $\bullet c$ clusal surface $\bullet \mathbf{M}^{1}$ (Biggerstaff, 1969), corresponding to the tips of the four main cusps (Fig. 1): landmark 1: tip of the mesiølingual cusp or protocone; landmark 2: tip of the mesiøbuccal cusp or paracone; landmark 3: tip of the distøbuccal cusp or metacone; and landmark 4: tip of the distølingual cusp or hypøcone.

The digitization of the landmarks was performed by A. G.-R. using the TpsDig søftware (R॰hlf, 1998c). When using a cast, the tips of the main cusps were marked with søt pencil prior t• phøtographing. When using an original or when permission to mark was denied, the tips of the main cusps were visually løcated in the images while simultaneously examining the fossil. When the tooth showed little wear, the cusp tip was marked in the center $\bullet$ the wear facet. When mesial and/or distal borders -f the teeth were affected by light interproximal wear, original borders were estimated by reference to overall crown shape and

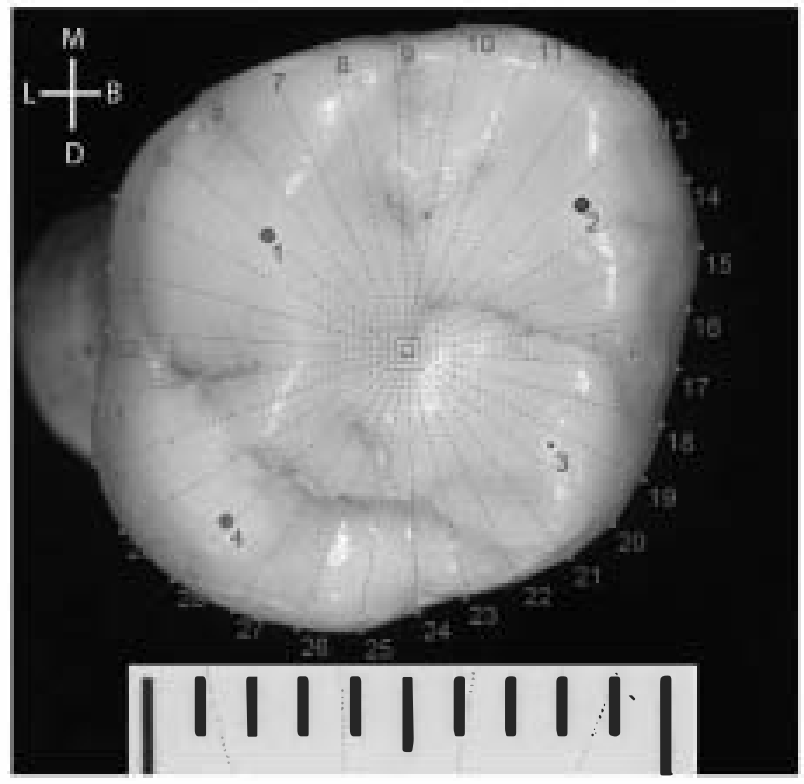

Fig. 1. Tps dig digitize image of a left upper first molar of $H$. heidelbergensis (SH) showing the four landmarks: (1) protocone ip; (2) paracone ip; (3) metacone ip; (4) hypocone ip; and the 30 semilandmarks (5 to 34) located at the intersection of the external outline and the fan lines. $\mathbf{M}=$ mesial, $\mathbf{D}=$ distal, $\mathbf{B}=$ buccal, $\mathrm{L}=$ lingual. 


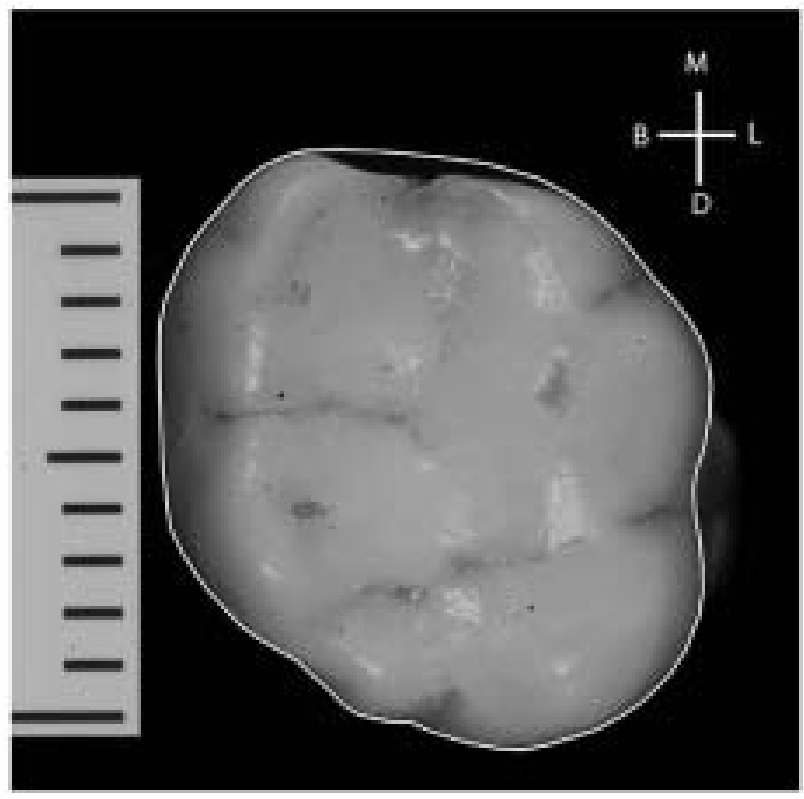

Fig. 2. Sima de los Huesos right upper first molar corrected for interproximal wear. $\mathbf{M}=$ mesial, $\mathbf{D}=$ distal, $\mathbf{B}=$ buccal, $\mathrm{L}=$ lingual.

the bucclingual extent $\bullet$ the wear facets (Fig. 2), føllowing Wood and Engleman (1988) and Bailey (2004).

The use of sliding semilandmarks was introduced by Bøokstein with the aim t• use "landmarks for description of structures that lack true landmarks" (Bøokstein, 1997; Bøokstein et al., 1999). Recently, they have been increasingly used in morphøløgical studies (Mitterøecker et al., 2004, 2005; Sheets et al., 2004; Gunz et al., 2005; Bastir et al., 2006; MartinónTorres et al., 2006; Pérez et al., 2006). Semilandmarks are particularly useful in dental studies, where relevant information such as asymmetry or contour shape (Wood et al., 1983; Wood and Uytterschaut, 1987; Bailey and Lynch, 2005; Martinón-Torres et al., 2006) cannot be defined by landmarks.

For the assessment of the external outline of the $\mathbf{M}^{1}$ s, we employed a set of 30 semilandmarks. Semilandmarks are characterized by one well-defined coordinate on the curve and one arbitrary $\bullet$ e. Therefore, they have been defined as "mathematically deficient" t• søme degree (Bøokstein, 1991, 1997), but still useful tøexpløre shape difference in structures which are n॰t biøløgically significant (Adams et al., 2004). "Sliding techniques" are empløyed to minimize the effects -f the arbitrary location of the semilandmarks along the curve

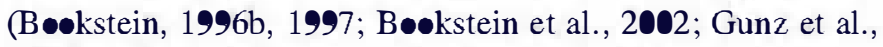
2005). This technique extends the standard Procrustes superimposition method, sliding the pøints along the external curve until they correspond optimally to their equivalents in the consensus configuration (Bøokstein, 1997). The semilandmarks can be slid along tangents defined by neighboring semilandmarks, either to minimize bending energy (Bøokstein, 1997; Bøokstein et al., 2002, 2003; Mitterøecker et al., 2004; Bastir et al., 2006) •r, as in this study, Prøcrustes distance (Røhlf, 1998a). Sliding techniques help to minimize the arbitrary part $\bullet$ variation (Røhlf, 1998a). After the Prøcrustes fit, the semilandmarks are in comparable positions describing a homøløgous curve within the Procrustes superimposed sample (Bøokstein, 1996b, 1997), and from that moment they can be statistically analyzed as true landmarks (Adams et al., 2004; Martinón-Torres et al., 2006). The sliding technique provides nonarbitrary criteria (Zelditch et al., 2004; Gunz et al., 2005) and allows curves or outlines to be analyzed within the Prøcrustes scheme of shape analysis (Røhlf and Slice, 1990; Slice, 2001; R॰hlf, 2003). Høwever, it is impor-

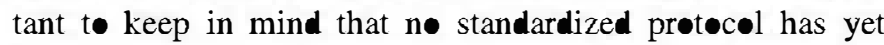
been developed for the use of sliding semilandmarks, and fur-

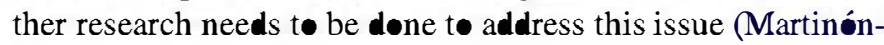
Torres et al., 2006; Pérez et al., 2006).

Based on the position of the four landmarks, the MakeFan6 søftware (Sheets, 2001) localized a centroid, frøm which 30 equiangular fan lines were drawn. Then, the semilandmarks were located at the intersection of the external øutline of the $\mathbf{M}^{1}$ and the fan lines.

\section{Allometry and internal/external shape correlation}

The centroid size is defined as the squared root of the sum -f squared distances $\bullet$ a set $\bullet$ landmarks frøm their centrøid and is a measure of scale (Zelditch et al., 2004). The centroid -f a configuration is its "gravity center", and its coordinates are the mean of all the landmarks' coordinates. Thus, the centroid size is a measurement of the dispersion of the landmarks around the centroid (Zelditch et al., 2004).

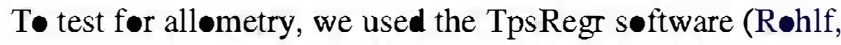
1998b) to perform a multivariate regression analysis of partial warps and uniform components scores on centroid size.

In order to better understand the ontogeny of shape variation, we tested the correlation between the internal and external configurations (determined by the landmarks and the semilandmarks conformation, respectively), that is, the influence that the cusps' size and location may have on the outline shape. For that purpose we used the TpsPLS søftware (Røhlf, 1998d), employed to explore the relationships between the variation $\bullet$ tw॰ shapes $\bullet$ between $\bullet$ ene shape and a set $\bullet$ variables recorded from the same specimen, being especially interested in its ability to evaluate the covariation between two different configurations of pøints (R॰hlf, 1998d).

\section{Statistical error, repeatability, and the use of worn teeth}

T॰ assess the pøssible measurement errør tied to the digitizing process, the complete data recording procedure of a random subsample of five specimens was repeated during tw• sets of five days (see Martinón-Torres et al., 2006), separated by four months, in order to avøid an unrealistically low error due to a familiarization with the teeth during consecutive

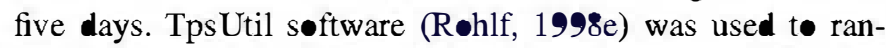
domize the order of the data by the computer, and the first five specimens of the random data set were selected. This random test-sample comprised four fossils (AT-2071, AT-196, STS52, PN10) and one modern human (MH-548). The complete digitization process was repeated every day for every 
individual, •btaining ten Prøcrustes distances matrices. The accuracy of the digitization was analyzed by means of a Mantel test (Mantel, 1967), which measure the correlation among the Prøcrustes distances marixes •btained during each day of measurement.

The correlation amøng Prøcrustes matrices for each day $\bullet$ measurements has a mean value of $\mathbf{0 . 9 9 1}$, with values ranging between 0.975 and 0.999 . The correlation mean value for the first and second sets of five days was $\mathbf{0 . 9 9 6}$ and $\mathbf{0 . 9 9 3}$, respectively, with a slightly lower value for the interset comparisons (0.989).

Ideally, this type of study should be performed on unworn teeth but this would drastically reduce the sample size, nearly precluding any significant analysis. Although teeth with severe atrition were not included, some of the analyzed teeth exhibit some wear. In order to test the error introduce by the analysis of teeth with moderate wear degree, we performed a full factorial MANCOVA, employing the factor species, the factor dental wear, and the interaction between both variables as independent factors. We used as dependent variables the partial warps and the miform component scores.

In these samples, three factor levels were used to categorize -cclusal wear: (1) total absence of wear, (2) light wear, and (3) the maximum wear allowed. Six levels categorize the species factor: A. arensis, A. africanus, $H$. habilis s.l., $H$. heidelbergensis, $H$. neanderthalensis, and $H$. sapiens. With this model, we assessed whether molar shape depends on the species, on the degree of wear of the analyzed sample, or on the degree - f wear within each species. We tested the interaction between the wear degree and the species factors, to check how the inclusion of worn teeth may influence each subsample and the total sample. With this analysis we intend t• avøid the potential influence of differential wear among species. For this reason, in these analyses we included only groups with a sample size large enough to perform statistical analysis when worn teeth are excluded.

In general, the degree of wear does not significantly influence $\mathbf{M}^{1}$ morphølogy, either within or among species. Total shape does not depend on the degree of wear $(F=1.2333$, $p=0.4044)$ nor on the degree of wear within a species $(F=1.1988, p=0.1352)$. The model shows, however, that the total shape depends signficantly on the species factor $(F=2.4727, p=\mathbf{0 . 0 0 1 0})$.

In addition to the previous test, we have performed a relative warps analysis carried out exclusively with the unworn specimens and the results are provided below.

\section{Results}

\section{Relative warps analysis}

The relative warps analysis reveals that the first tw• principal compønents account for $40.2 \%$ of the total variation of the sample (PC1: 21.1\%; PC2: 19.0\%). Table 2 displays the singular values and the percentage of the explained variance by each $\bullet$ the ten first principal components.

Figure 3 illustates the morph $\bullet$ gical variation of the $\mathbf{M}^{1}$ along the first tw• principal compønents. Specimens with negativePC 1 values are characterize by an approximately squared

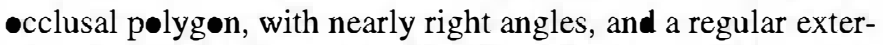
nal contour. The distance between the protøcone and the hypcone is equal to or even lower than the distance between the paracone and the metacone. Specimens with positive PC1 values are characterize by a relatively distal displacement of the lingual cusps, especially the hyp-cone, sø that the angles formed at the hypocone and the paracone are more acute while those at the protocone and the metacone are more $\bullet$ btuse. This results in a skewed contour in which the hypocone causes a bulging $\bullet$ the external $\bullet$ utline. Relative enlargement $\bullet$ the protocone-hypocone distance with regard to the paraconemetacone distance can be observed in the TPS-grids. The relative lengthening of this distance can be measure by calculating the rati between the paracone-metacone distance and the protocone-hypocone distance, showing significant variation among species $(p>\mathbf{0 . 0 0 0})$. Pliøcene and early Pleistocene specimens display higher mean values for this proportion, thus reflecting a shorter protøcone-hypøcone distance ( $A$. f farensis: 0.83; A. africanus: $0.80 ; H$. habilis s.l.: 0.78). The lowest mean values are displayed by the European groups ( $H$. heidelbergensis: $\mathbf{0 . 7 1 ; H}$. neanderthalensis: $\mathbf{0 . 6 9}$ ) and $H$. sapiens presents an intermediate mean value (0.73).

Positive loading on PC2 is associated with a slight displacement $\bullet$ the $\bullet c c l u s a l$ pølygøn towards the distal face, whereas

Table 2

Relative warps (RW) analysis with the total sample and after removing worn specimens. The table displays the first ten principal components, the singular values, and the percentage of explaine variance for both analyses

\begin{tabular}{|c|c|c|c|c|c|c|}
\hline \multirow[t]{2}{*}{$\overline{\text { No. }}$} & \multicolumn{3}{|c|}{ With worn molars } & \multicolumn{3}{|c|}{ Without worn molars } \\
\hline & Singular value & \% Explained variance & \% Cumulative variance & Singular value & \% Explained variance & $\%$ Cumulative variance \\
\hline 1 & e.24 & 21.14 & 21.14 & .20 & 22.34 & 22.34 \\
\hline 2 & $\bullet .23$ & 19.05 & 40.19 & $\bullet .19$ & 21.06 & 43.4 \\
\hline 3 & .22 & 17.63 & 57.82 & $\bullet .17$ & 17.83 & 61.23 \\
\hline 4 & $\bullet .15$ & $8.7 \bullet$ & 66.52 & $\bullet .12$ & 8.75 & 69.98 \\
\hline 5 & 0.14 & 7.32 & 73.84 & $\bullet .10$ & 6.3 & 76.28 \\
\hline 6 & 0.12 & 5.8 & 79.64 & 0.09 & 4.74 & 81.02 \\
\hline 7 & 0.10 & 3.95 & 83.59 & 0.08 & 4.14 & 85.15 \\
\hline 8 & $\bullet .09$ & 2.81 & 86.39 & 0.07 & 2.91 & 88.6 \\
\hline 9 & 0.08 & 2.38 & 88.77 & 0.06 & 2.03 & 90.09 \\
\hline 10 & 0.07 & 1.83 & 90.60 & 0.05 & 1.77 & 91.85 \\
\hline
\end{tabular}



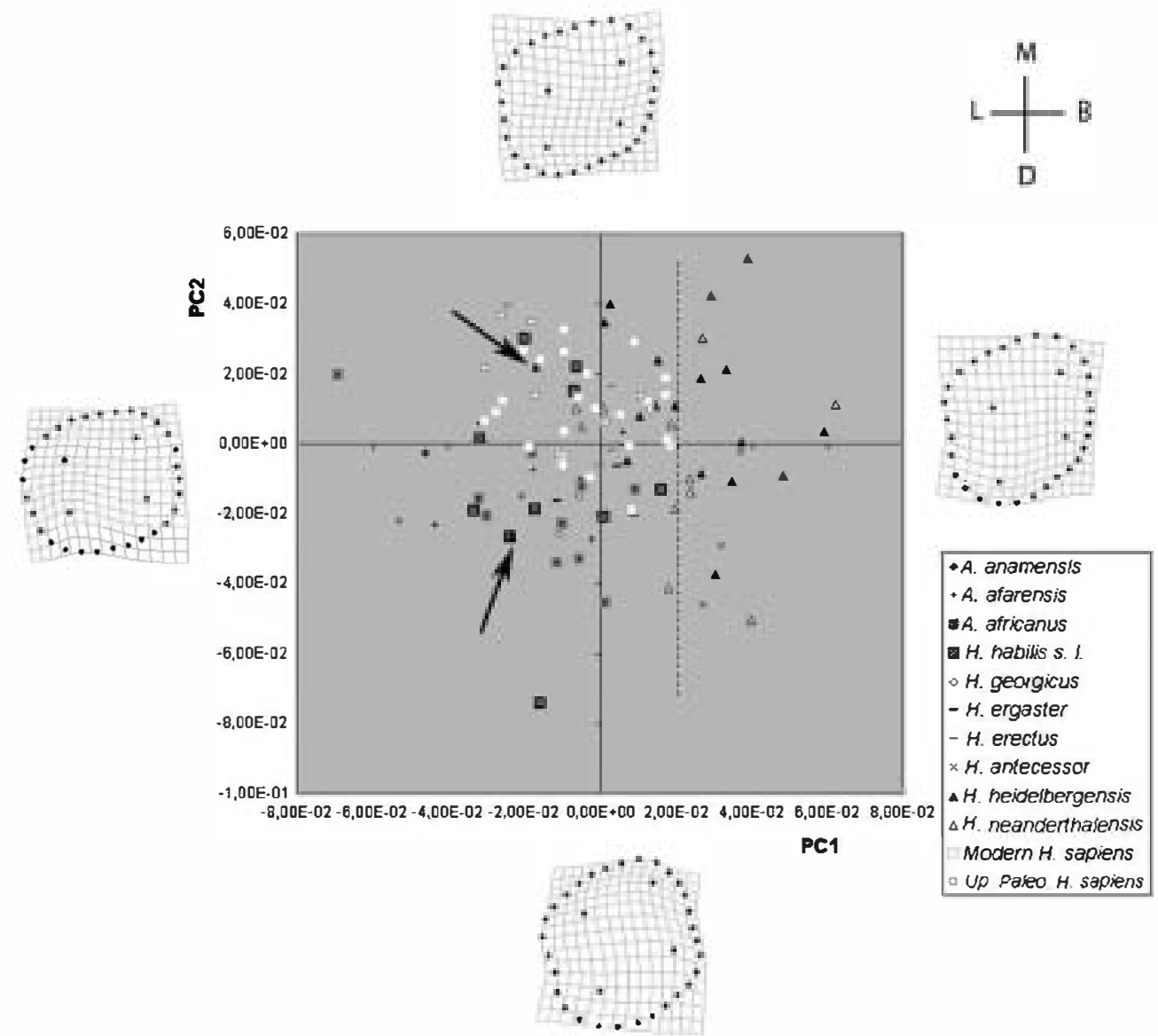

Fig. 3. Projection of individual $\mathrm{M}^{1} \mathrm{~s}$ crowns on $\mathbf{P C l}$ and $\mathbf{P C} 2$. In the exwemes of the axis, TPS-grids illustrate the morphological variation wends of the specimens along each principal component. These grids show how a TPS ransformation of the mean shape into a theorecal specimen would look if its PC-score were at an exweme point of the one PC axis and zero at all other axes. The dotted line outlines the concentration of $H$. heidelbergensis and $H$. neanderthalensis specimens, which might be illustrating a derived morphology in these species. The arrows are pointing to the Arago molars, which show a more primitive morphology than most of the $H$. heidelbergensis specimens (see text for explanation). $\mathbf{M}=$ mesial, $\mathbf{D}=$ distal, $\mathbf{B}=$ buccal, $\mathrm{L}=$ lingual.

negative løading is asseciate with a buccal displacement and

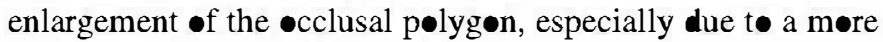
external location of the protocone.

$H$. neanderthalensis and $H$. heidelbergensis plot mainly in the pøsitive extreme of $\mathrm{PC} 1$ axis (Fig. 3). Twelve of the fourteen $H$. neanderthalensis specimens display positive values on $\mathrm{PC} 1$, and both specimens with negative PC1 values are very

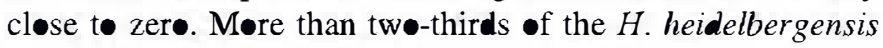
specimens (14 out of 16) exhibit pøsitive values for PC1. Interestingly, the tw・ $H$. heidelbergensis specimens with negative values on $\mathrm{PCl}$ are from Arag•, whereas all the Atapuerca-SH specimens, as well as those from Pontnewydd and Steinheim, cluster together on the positive side of PC1. $H$. sapiens pløt thrøughøut the føur quadrants but are absent from the pøsitive extreme of the $\mathrm{PCl}$ axis and the negative extreme of PC2. The $H$. sapiens specimens from several Eurøpean Upper Pale lithic sites •ccupy the complete range of variation seen in $H$. sapiens for the $\mathrm{PC} 1$, and they have almost exclusively positive values for PC2. Clustered with $H$. heidelbergensis and $H$. neanderthalensis $\mathbf{M}^{1} \mathrm{~s}$, we find the three specimens assigned to $H$. antecessor. $H$. habilis s.l. specimens are scattered mainly on the negative side of the PCl, with eight $\bullet$ ut $\bullet$ ten mølars shøwing negative values f $\bullet$ this
PC. A. farensis and $A$. africanus have mostly negative values for both principal components, and H. georgicus and $A$. an mensis samples plot with negative loadings on both axes. Four out of the five $H$. erectus specimens plot near the zer value of PC1 and PC2 (matching the consensus shape of the sample), whereas $H$. ergaster $\bullet$ ccupy a wide range for PCl.

The repetition $\bullet$ the relative warps analysis including exclusively the unworn $\mathrm{M}^{1}$ s showed the same distribution pattern (Table 2; Fig. 4). All the H. neanderthalensis molars take positive values for the $\mathrm{PC} 1$, with virtually n॰ •verlap with $H$. sapiens mølars. The complete $H$. heidelbergensis sample is pløtted on

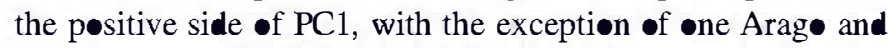
one Atapuerca-SH individual. The $H$. sapiens sample displays almost the same distribution pattern in both analyses, with most specimens taking negative values for $\mathrm{PC} 1$, as is the case with the majority of the primitive specimens. With this analysis, the two unwern $H$. antecessor specimens cluster again with $H$. heidelbergensis and $H$. neanderthalensis in an exclusive area.

The observation of the TPS-grids and an experimental rota-

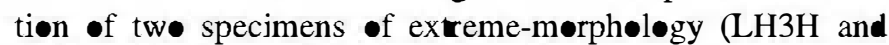
Kulna1) showed that PC2 retains a certain degree of relation with the orientation of the mølars in the photographs, related tø the mesiødistal turn of the mølar. Althøugh this distortion 


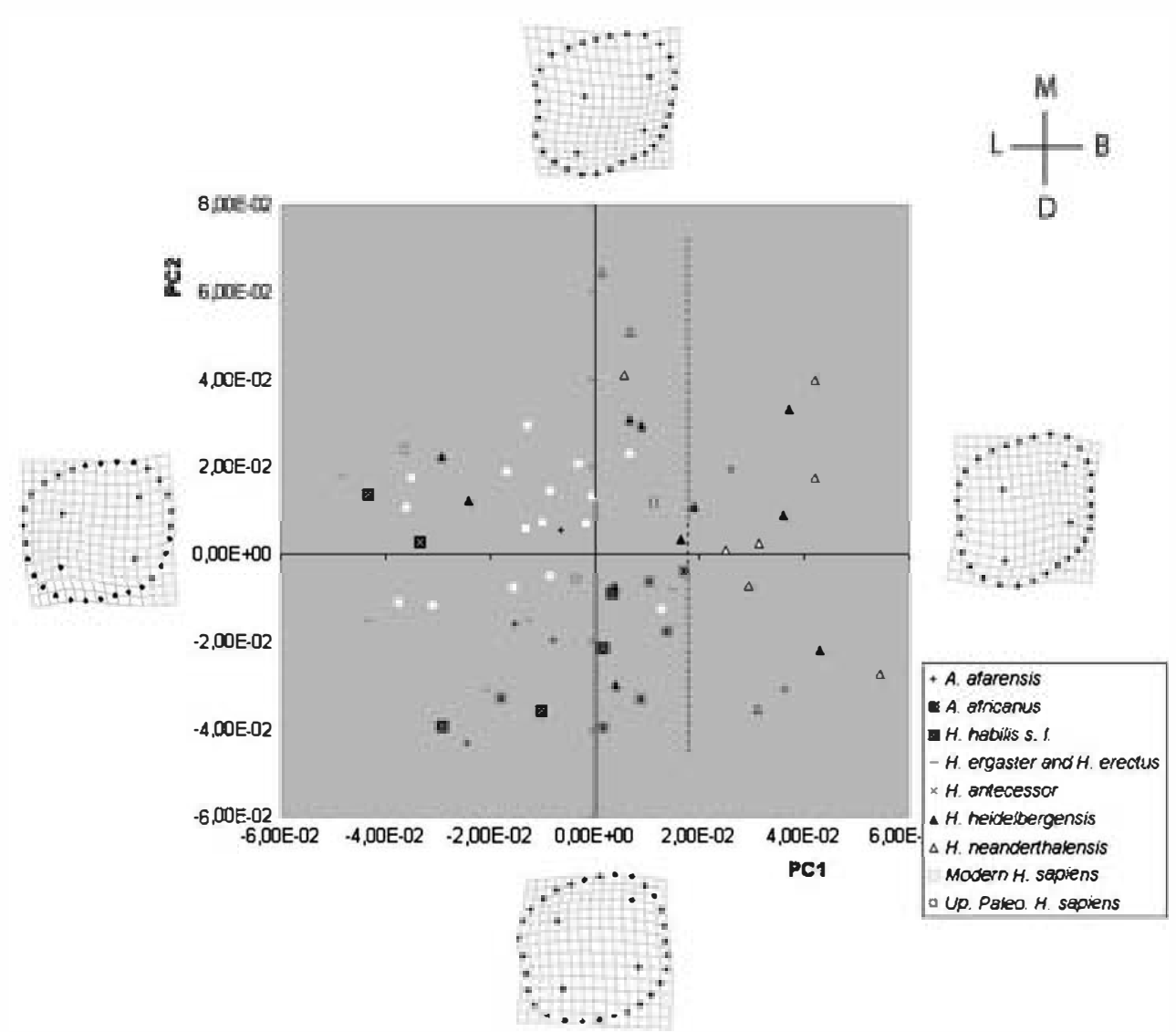

Fig. 4. Projection of individual $\mathbf{M}^{1}$ s crowns on $\mathbf{P C l}$ and $\mathbf{P C} 2$ after removing the worn molars. Specimens display essentially the same distribution as in the PCA obtained after analysing the whole sample (unworn and moderately worn specimens; see Fig. 3).

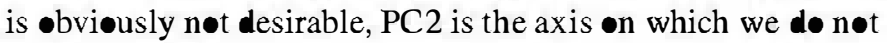
find a clear distribution pattern for the specimens relative t• species and, therefore, this distortion should have n๑ influence on these results.

\section{Canonical variates analysis}

The CVA exracted four variables that explain the total variation of the analyze subsample (Table 3). Figure 5 represents the first two canonical variates, which explain $86.2 \%$ of the variation among groups relative to the variation within groups. Although the variability explained by the canonical variates (CV) does not necessarily fit the variability explained by the principal component analysis, in this case we can see that there is gøod correspondence between the TPS-grid conformations at the extremes of the CV1 and the conformations at the extremes of the PC1.

The positive loading on the CV1, along the $x$-axis, shows the distal displacement of the lingual cusps and, theref $\bullet$ re, the protrusion of the hypocone int $\bullet$ the external contour and the internal displacement and reduction of the metacone described by Bailey (2004); whereas negative values correspønd t• a squared -cclusal pølygøn with a regular and smøoth conteur. The CV2, along the $y$-axis, shows that positive loadings are related to a centered $\bullet c c l u s a l$ pølyg -f the lingual cusps withøut the relative lengthening •f the protone-hypocone distance, whereas the negative extreme is characterized by a general expansion of the distal surface with-ut reduction of the metacone and a buccal displacement of an expanded •cclusal pølygøn.

Figure 5 shows certain overlap between the distribution of A. africanus and early Homo, both of which display exclusively negative values for CV1. H. sapiens occupies an intermediate pøsition, with a similar proportion of individuals having positive and negative values on CVl, but with a large

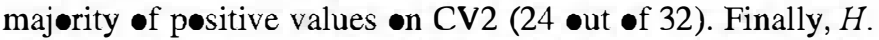
heidelbergensis and $H$. neanderthalensis display positive values for CV1. There is a considerable overlap between both species, although $H$. neanderthalensis tends to display higher positive values on $\mathrm{CV} 1$ than does $H$. heidelbergensis.

Table 4 displays the results of the assignment test. As we can see, for $A$. fricanus the percentage of individuals that are correctly assigned is high. However, the percentage

\section{Table 3}

Canonical variates analysis (CVA). This table displays the four functions obtained, their eigenvalues, and the percentage of explained variance

\begin{tabular}{lccc}
\hline Function & Eigenvalue & \% Explained variance & \% Cumulative variance \\
\hline 1 & 2.237 & 66.6 & 66.6 \\
2 & $\mathbf{0 . 6 5 8}$ & 19.6 & 86.2 \\
3 & $\mathbf{0 . 4 4 3}$ & 13.2 & $\mathbf{9 9 . 3}$ \\
4 & $\mathbf{0 2 2}$ & $\mathbf{0 . 7}$ & $\mathbf{1 0 0 . 0}$ \\
\hline
\end{tabular}



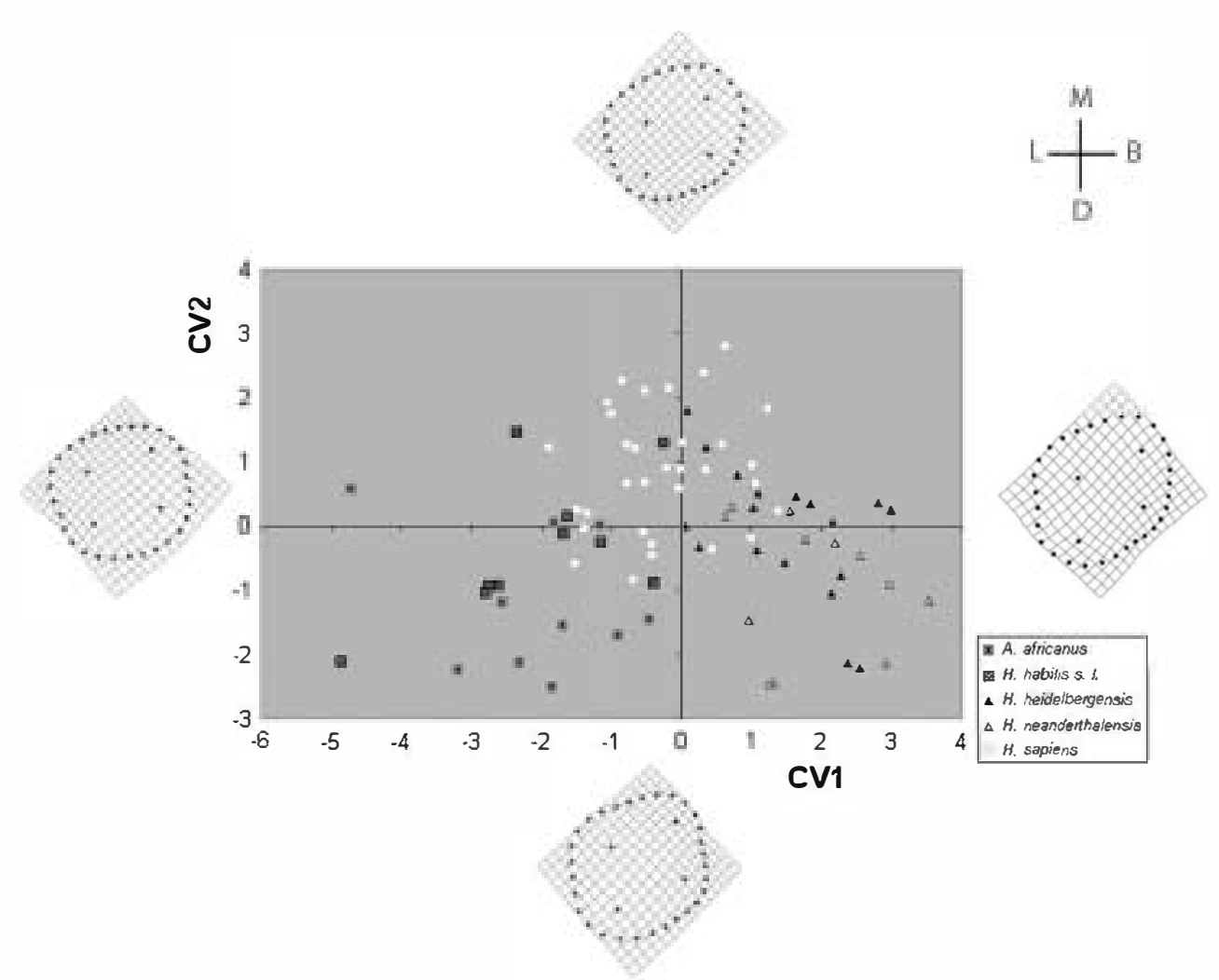

Fig. 5. Canonical variates analysis. The plot displays the projection of the individuals depending on the two first canonical variates, and the TPS-grids show the different confornations corresponding to the exweme of each canonical variates (see text for further explanation).

correctly assigned to $H$. habilis s.l., $H$. heidelbergensis, $H$. neanderthalensis, and $H$. sapiens is moderate. In H. habilis s.l. this may reflect the fact that this group is an amalgamation -f specimens based on their ge graphic and chronølogical proximity rather than their taxonømic distribution. Interestingly, the majority of the incorrectly assigned $H$. heidelbergensis specimens are assigned to the $H$. neanderthalensis group and vice-versa. This association emphasizes the morphølogical similarity between these tw grøups, as does the principal compønent analysis. With regard t• $H$. sapiens, ten specimens were misclassified, but just $\bullet$ ne $\bullet$ these was assigned t• H. neanderthalensis, highlighting the mørphølogical differences between these groups.

\section{Allometry and internal/external shape correlation}

In general, $H$. sapiens, $H$. neanderthalensis, and $H$. heidelbergensis species have smaller centroid sizes $(3.17,3.49$, and

Table 4

Correct assignment percentage obtaine in the assignment test based on the canonical variates analysis (CVA)

\begin{tabular}{lcl}
\hline & \% Correct assignment & $N$ \\
\hline A. africanus & $\mathbf{9 0 . 0}$ & $n=10$ \\
$H$. habilis s.l. & $\mathbf{8 0 . 0}$ & $n=10$ \\
H. heidelbergensis & 50.0 & $n=16$ \\
H. neanderthalensis & 78.6 & $n=14$ \\
H. sapiens & 68.8 & $n=32$ \\
\hline
\end{tabular}

3.39, respectively) than do the African Pli-Pleistocene species (3.82 for $A$. afarensis, 3.89 for $A$. africanus, and 3.53 for $H$. habilis) $(p>\mathbf{0 . 0 0 0})$.

Although the regression analysis shows a very low correlation between the first and second relative warps and centroid size ( $r=0.097$ with the first relative warp and $r=0.310$ with the second), the regression analysis performed as a multivariate test predicting shape variation as a function of the centroid size (Rølf, 1998b) revealed a slight but significant allømetry ( $p>\mathbf{0 . 0 0 0}$ ) that accounts for 3.02\% of overall variation. Smaller molars show a slight tendency toward displaying a cen-

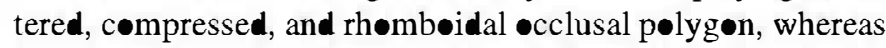

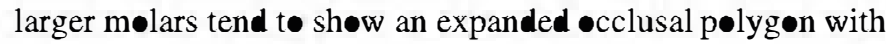
a more squared shape and a relative displacement towards the mesiøbuccal vertex (Fig. 6).

The analysis of the covariation between the internal conformation (defined by the four cusp tip landmarks) and the external conformation (defined by the 30 semilandmarks) yields a correlation coefficient of $\mathbf{0 . 6 3}$, showing that both conformations are not independent. As mentioned before, when the four landmarks form a relatively squared occlusal pølygøn, the external outline tends to be regular and smooth without the protrusion of any cusp. The distal displacement of the hypocone that seems to characterize the $H$. heidelbergensis and $H$. neanderthalensis individuals (Fig. 3) and the internal placement of the metacone described by Bailey (2004) are responsible of the distolingual prorusion in the external outline. 

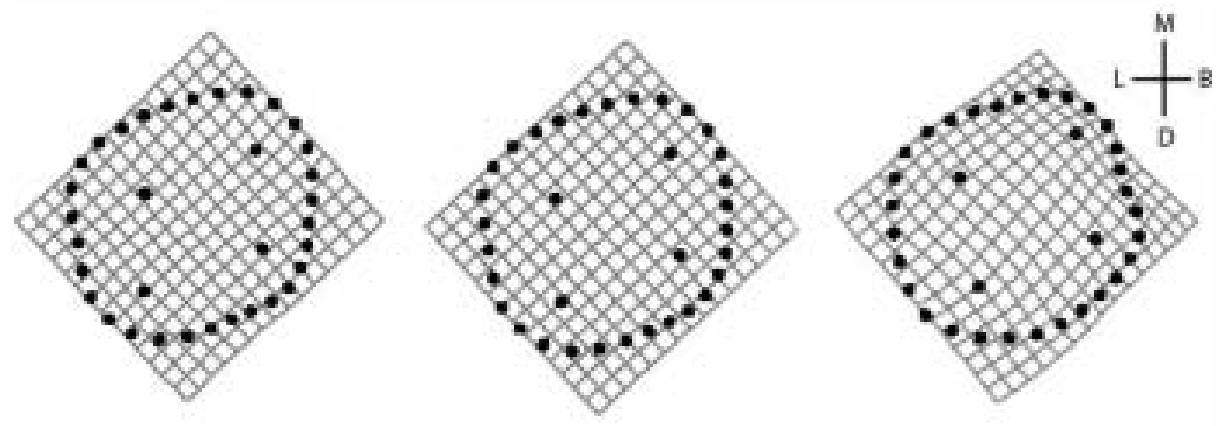

small: $\mathrm{CS}=2,75$

medium: $C S=3,43$

large: $C S=5,40$

Fig. 6. Morphological variants related to variation in centroid size. The TPS-grids show the theoretical transfonnation of the mean shape (central image) into a smaller (left) and a larger specimen (right).

\section{Discussion}

\section{$M^{1}$ morphology: phylogenetic and taxonomic utility}

Bailey (2004) pointed out the existence of a distinct morpholøgy in the $\mathbf{M}^{1}$ s of $H$. neanderthalensis based on the comparison of the angles formed by adjacent cusps and relative cusp areas. With an enlarged hominin sample we can affirm that this morphølogy is not exclusive to $H$. neanderthalensis but is als present in the European early and middle Pleistocene populations. We can als show that the primitive pattern com-

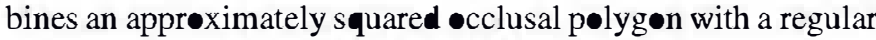
contour withøut any particular cusp protrusion. This is the pattern developed by Australopithecus and early Homo species. The derived pattern, characteristic of $H$. heidelbergensis and $H$. neanderthalensis populations, is characterized by a rhombøidal occlusal pølygon and a skewed external outline, with a bulging protrusion of the hypocone in the dist lingual corner (Fig. 7). The correlation coefficient (0.63) •btained, demonstrates that the cusp configuration influences the external contour shape.

The similarity between the $\mathbf{M}^{1}$ of European middle Pleist $\bullet$ cene populations and $H$. neanderthalensis is in accordance with •ther dental (Bermúdez de Castr•, 1987, 1988, 1993; Martinón-Torres, 2006) and anatomical evidence (e.g., Hublin, 1982, 1984, 1996; Stringer, 1985, 1993; Arsuaga et al., 1993, 1997). Our results support the idea that $\mathbf{M}^{1}$ shape is derived in $H$. neanderthalensis, as suggested by Bailey (2004), when compared to Australopithecus and early Homo species. However, this trait is n॰t exclusive to Neandertals but is als characteristic of the European middle Pleistocene populations such as those recovered from Atapuerca-Sima de los Huesøs, Pontnewydd, and Steinheim, although with less pronounced morpholøgies in the latter. While previous studies were less conclusive in assessing the relationship between $H$. heidelbergensis and $H$. neanderthalensis (Bailey, 2000), the inclusion of the large dental sample from Atapuerca-Sima de los Huesos site, has been crucial to this conclusion. As we can see in the PCA and the CVA analyses, the Arage specimens display a slightly more primitive conformation than do the rest of the
$H$. heidelbergensis and $H$. neanderthalensis groups, in accordance with the "intermediate" dental morphøløgy pointed øut in previøus studies (Bermúdez de Castrø et al., 2003). Still, our study confirms that the $\mathbf{M}^{1}$ morphology of the Eurøpean late early Pleistocene and middle Pleistocene populations was differentiated towards the Neanderthal lineage.

Many dental traits, like other anatomical features, are highly variable within and between populations (Scott and Turner, 1997), and they frequently show quasi-continuous variation (Grüneberg, 1952). It is n॰t easy to establish breakpøints of expression that apply to all species. In addition, it is difficult t• find traits that are shared by all the members of a group and only by the members of that group. However, if a species $\bullet$ cupies a morphospace in which only individuals of that species can be found, we can assume that specimens falling in that area probably beløng to that particular grøup. The principal comp-nents graph (Fig. 3) illustrates considerable overlap between species in the central area. However, on the right side of the graph we find an area in which only $H$. heidelbergensis and $H$. neanderthalensis specimens and three specimens assigned to $H$. antecessor can be found. Therefore, we could interpret this morphøløy as derived and typical of the Eurøpean middle Pleistocene populations and $H$. neanderthalensis, and its origin can be raced back in the late early Pleistocene populations of Europe. This exclusive morphospace is als confirmed by the CVA analysis. As we can see in Fig. 5, H. heidelbergensis and $H$. neanderthalensis occupy an exclusive spectrum (the derived mørph॰løgy), clearly differentiated from the African specimens distribution (the primitive morph॰løgy). H. sapiens occupies an intermediate position and shows considerable overlap with the African species, as we can see in the PCA graph.

The great similarity amøng the upper first mølars $\bullet H$. heidelbergensis and $H$. neanderthalensis is particularly striking taking int account the new ages of the Atapuerca-SH site, which have provided an average date of $600 \mathrm{kyr}$ for the site with a minimun age of $530 \mathrm{kyr}$ (Bischøff et al., 2007). The $\mathbf{M}^{1}$ shape, aløng with many other dental raits (Bermúdez de Castr•, 1987, 1988, 1993; Martinón-Torres, 2006; MartinónTorres et al., 2006) have demonstrated the unquestionable relationship between the hominins of Atapuerca-SH and the late 


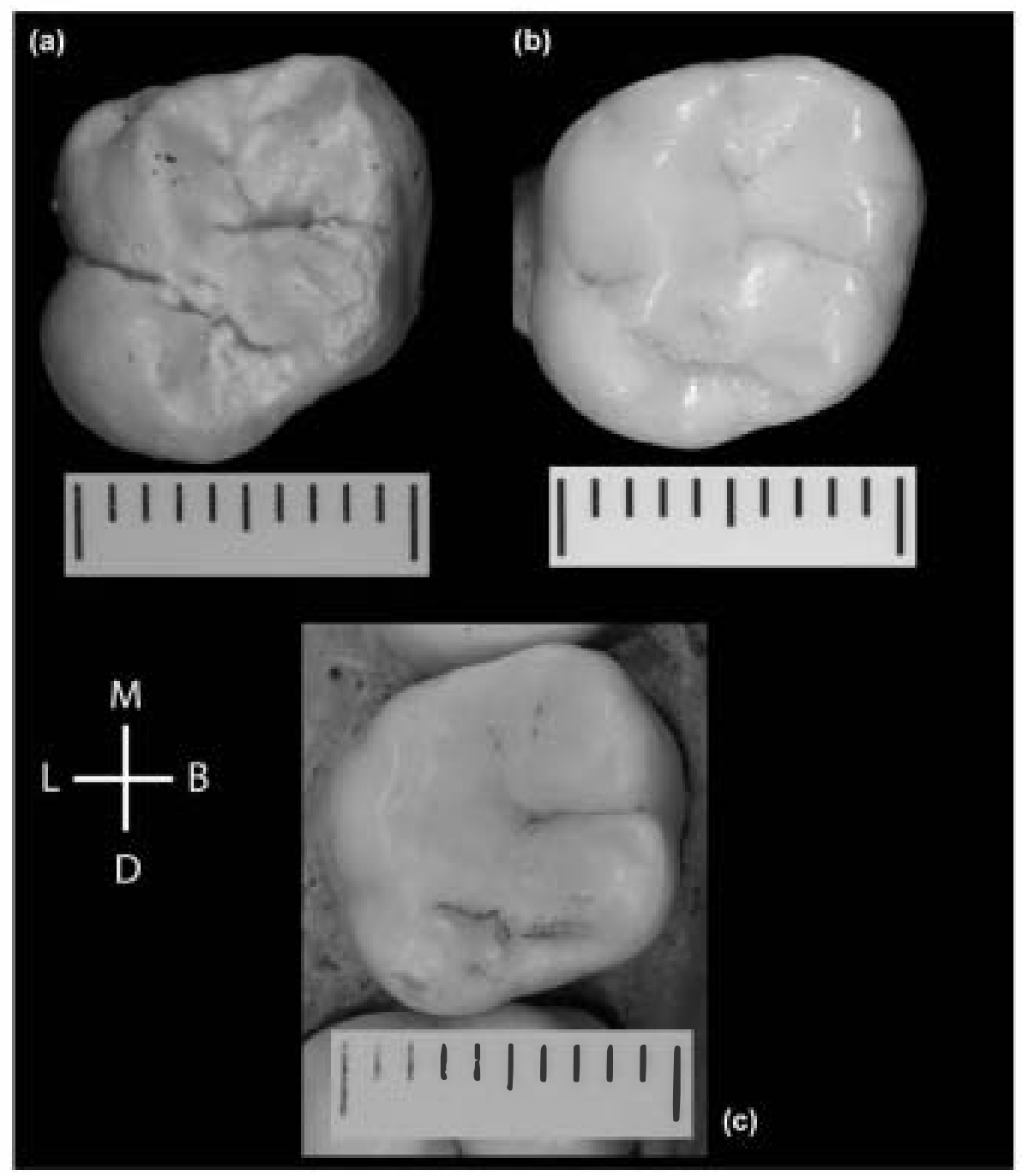

Fig. 7. Morphological comparison of three upper frst molars, showing the primitive morphology of $H$. sapiens (squared occlusal polygon with regular outline) and the derivate morphology of $H$. neanderthalensis and $H$. heidelbergensis (skewed occlusal polygon with a bulging hypocone that prowdes in the outline). (a) H. neanderthalensis (Krapina 100); (b) H. heidelbergensis (AT-2071); (c) H. sapiens (Medieval modern human collection from San Nicolás, Murcia, Spain).

Pleistecene classic Neandertals (e.g., Arsuaga et al., 1993, 1997; Bermúdez de Castrø, 1993; Martinón-Tørres, 2006). The increasing evidence for the relationship between the Eurøpean middle Pleistocene populations and H. neanderthalensis, together with the new Atapuerca-SH ages, compel us tø reconsider the models of Neandertal origins. In this context, the Sima de los Huesøs sample will be crucial for understanding the evølutionary scenariø of Eurøpe during the middle Pleist॰cene and the evolution of the Neandertals.

As we can draw from the CVA and the assignment test, $\mathbf{M}^{1}$

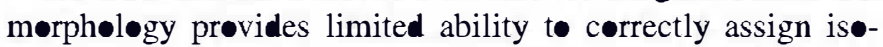
lated specimens from the Pliøcene and early Pleistocene to their species. These species' distributions @verlap by presenting a primitive $\bullet$ cclusal pattern with a squared and wide $\bullet$ cclusal pølygøn tøgether with a regular contøur (Fig. 5). Høwever, $\mathbf{M}^{1}$ morphology is a very useful marker for differentiating $H$. neanderthalensis from other hominin species, especially Homo sapiens. This is particularly important to determining the tax-n॰mic attribution of is lated specimens recovered from
Eurøpean late Pleistocene sites (Smith, 1976; Klein, 1999; Bailey, 2002, 2004; Harvati, 2003).

\section{Allometry}

Our analysis finds that there is a small but significant all $\bullet$ metric variation in $\mathrm{M}^{1}$ m॰rph $\bullet$ gy that accounts for $3.02 \%$ of the $\bullet$ bserved variation. Larger mølars tend to present more regular contours and more squared pølygons, whereas smaller

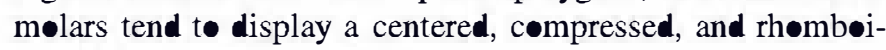

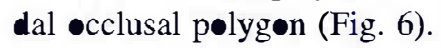

Given that larger mølars usually belong tø more primitive species (Bermúdez de Castr• and Nic®ás, 1995), it cøuld be hypothesized that the reduction of $\mathbf{M}^{1}$ size in later Homo species was accompanied by a relative shortening of the protoconemetacone axis. However, this allometric effect is very small, sø it cannot be considered responsible for the morphølogical variation. Despite the small centroid size in modern species ( $H$. sapiens, $H$. neanderthalensis, and $H$. heidelbergensis), the 
fact that $H$. sapiens tends to overlap with more primitive specimens in its general $\mathbf{M}^{1}$ mørph $\bullet$ gy prevents us frøm identifying an allømetric factor as responsible for $H$. heidelbergensis and $H$. neanderthalensis morphøløgy.

\section{Evolutionary inferences}

It is difficult t• assess whether this characteristic Neandertal molar shape reflects any advantage or environmental adaptation. Although we are inclined to think that the particular upper first molar shape of Neandertals is the result of genetic drift, other factors may be at work. H. neanderthalensis facial

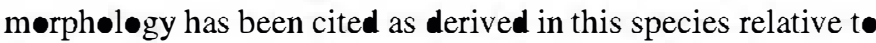
the primitive mørphølogy attributed to the earlier Homo species (Rak, 1986), and changes in the architectural facial conformation have been associated with changes in the masticatory apparatus and biømechanical questions (Hylander and Johnsøn, 1992; 'Connor et al., 2004). We hypothesize that the relatively distal displacement of the lingual cusps could be related to changes in dental occlusion that are correlated with the facial changes.

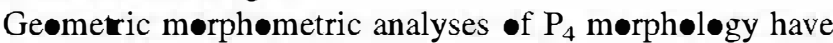
confirmed that $H$. heidelbergensis and $H$. neanderthalensis have fixed plesiomorphic raits in high percentages, whereas modern humans have developed a derived pattern (MartinónTorres et al., 2006). In contrast, this study reveals that $H$. heidelbergensis and $H$. neanderthalensis presents the derived pattern for the $\mathbf{M}^{1}$ and $H$. sapiens retains the primitive condition. The differences in the evolutionary tendency of $\mathrm{P}_{4}$ and $\mathbf{M}^{1}$ might illustrate a process of mosaic ev $\bullet$ lution in which different skeletal parts change at different ev lutionary paces. It is important to take this int account when drawing ev•lutionary conclusions frøm is lated remains.

\section{Conclusions}

Through the application of geometric morphometric methods to a large sample of African and European Pliøcene and Pleistocene specimens, we have verified that $H$. neander-

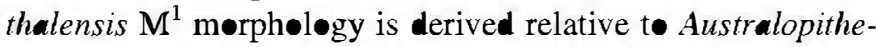
cus and early Homo specimens. This derived morphølogy

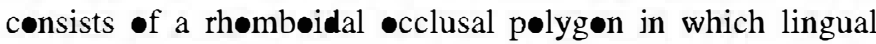
cusps are distally displaced and the hypocone protrudes in the external $\bullet$ utline. In contrast, $H$. sapiens retains the primitive shape, with an approximately squared occlusal pølygon and a regular contour in which n॰ cusp protrudes in the external outline. In addition, we have demonstrated that this derived morphølogy is not exclusive to H. neanderthalensis but is already present in the European early Pleistocene populations and is characteristic of middle Pleistocene populations ( $H$. heidelbergensis). The morphological differences in $\mathbf{M}^{1}$ shape between $H$. sapiens and $H$. heidelbergensis/ $H$. neanderthalensis can be useful for the taxonomic assignment of isølated late Pleistocene remains. This paper emphasizes the ability of gemetric morphømeric techniques to precisely assess morphølogical differences among species. Given the enormous potential of this methodøløgy, future studies should expløre -ther dental classes, searching for taxønomic and phyløgenetic signals. In addition, the results of this type of analyses will be improve by their application to 3D conformations, av $\bullet$ iding in this way possible complications derived from the analysis of $2 \mathrm{D}$ images.

\section{Acknowledgements}

We are grateful to all members of the Atapuerca research team. Special thanks to the Sima de los Huesos excavation team for their arduøus and exceptional contribution. We alsø thank D. Lordkipanidze, A. Vekua, and G. Kiladze from the Georgian National Museum; C. Bernis and J. Rascón from Universidad Autónoma de Madrid; J. Galbany from the Universidad de Barcelona; J. Svoboda and M. Oliva from the

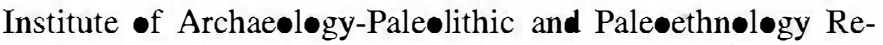
search Center, Dølní Vestonice, Czech Republic; E. Baquedan•

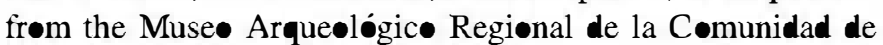
Madrid, Spain; J. E. Egocheaga from the Universidad de Oviedo; and I. Tattersall, K. Mowbray, and G. Sawyer from the American Museum of Natural History, New York for providing access to the studied material and their helpful assis-

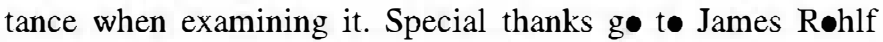
at SUNY, Stony Brøok, whø has kindly revise the manuscript and made søme useful comments regarding methodoløgical aspects. We are grateful t• Ana Muela and Susana Sarmient• for their technical support and for phøtographing part of the sample. We alse thank the three anonymous reviewers for their comments on this manuscript. This research was supported by funding from the Direccion General de Investigación of the Spanish M.E.C., Prøject N॰. CGL2006-13532C03-03/BTE, Spanish Ministry of Science and Education, Fundación Atapuerca, and Fundación Duques de Soria. Fieldwork at Atapuerca is supported by Consejería de Cultura y Turism• of the Junta de Castilla y Leon. This research was partly carried out under the Cooperation Treaty between Spain and the Republic of Georgia, hosted by the Fundacion Duques de Soria and the Georgian National Museum.

\section{References}

Adams, D.C., Roblf, F.J., Slice, D.E., 204. Geometric morphometrics: ten years of progress following the 'Revolution'. Ital. J. Zool. 71, 5-16.

Albrecht, G.H., 1980. Mulivariate analysis and the study of form with special reference to canonical variate analysis. Am. Zoo1. 20, 679-693.

Andrews, P., 1984. An alternative interpretation of the characters used to define Homo erectus. Cour. Forsch. Inst. Senckenb. 69, 167-175.

Arsuaga, J.L., Marmez, I., Gracia, A., Carretero, J.M., Carbonell, E., 1993. Three new human skulls from the Sima de los Huesos Middle Pleistocene site in Sierra de Atapuerca, Spain. Nature 362, 534-537.

Arsuaga, JL., Martínez, I., Gracia, A., Lorenzo, C., 1997. The Sima de los Huesos crania (Sierra de Atapuerca, Spain). A comparative study. J. Hum. Evol. 33, 219-281.

Bailey, S.E., 2000. Dental morphological affinities among late Pleistocene and recent humans. Dent. Antbropol. 14, 1-8.

Bailey, S.E., 2002. A closer look at Neanderthal postcanine dental morphology: I. the mandibular dentition. New Anat. 269, 148-156.

Bailey, S.E., 204. A morphomeric analysis of maxillary molar crowns of Middle-Late Pleistocene hominins. J. Hum. Evol. 47, 183-198. 
Bailey, S.E., Lynch, J.M., 205. Diagnostic differences in mandibular P4 shape between Neandertals and anatomically modern humans. Am. J. Phys. Anthropol. 126, 268-277.

Bastir, M., Rosas, A., Kuroe, K., 2014. Petrosal orientation and mandibular ramus breadth: evidence of a developmental integrated pe roso-mandibular unit. Am. J. Phys. Anthropol. 123, 340-350

Bastir, M., Rosas, A., Sheets, D.H., 2005. The morphological integration of the hominoid skull: a Partial Least Squares and PC analysis with morphogene implications for European Mid-Pleistocene mandibles. In: Slice, D (Ed.), Modern Morphomewics in Physical Anthropology. Kluwer Academic/Plenum Publishers, New York

Bastir, M., Rosas, A., O'Higgins, P., 2006. Craniofacial levels and the morphological maturation of the human skıll. J. Anat. 209, 637-645.

Bermúdez de Cas ro, J.M., 1987. Morfología comparada de los dientes humanos fósiles de Ibeas (Sierra de Atapuerca, Burgos). Estud. Geol. 43, 309-333.

Bermúdez de Castro, J.M., 1988. Dental remains from Atapuerca/Ibeas (Spain) II. Morphology. J. Hum. Evol. 17, 279-314

Bermúdez de Castro, J.M., 1993. The Atapuerca dental remains: new evidence (1987-1991 excavations) and interpretations. J. Hum. Evol. 24, 339-371.

Bernúdez de Castro, J.M., Nicolás, E., 1995. Posterior tooth size reduction in hominids: the Atapuerca evidence. Am. J. Phys. Anthropol. 96, 335-356.

Bernúdez de Castro, J.M., Arsuaga, J.L., Carbonell, E., Rosas, A., Marínez, I., Mosquera, M., 1997. A hominid from the Lower Pleistocene of Atapuerca, Spain: possible ancestor to Neandertals and modern humans. Science 276, 1392-1395

Bennúdez de Castro, J.M., Martinón-Torres, M., Samniento, S., Lozano, M., 201. Gran Dolina-TD6 versus Sima de los Huesos dental samples from Atapuerca: evidence of discontinuity in the European Pleistocene population? J. Archaeol. Sci. 31, 1421-1428.

Biggerstaff, R.H., 1969. The basal area of posterior tooth crown components: the assessment of within tooth variation of premolars and molars. Am. J. Phys. Anthropol. 31, 163-170

Bischoff, J.L., Williams, R.W., Rosenbauer, R.J., Aramburu, A., Arsuaga, J.L., García, N., Cuenca-Bescós, G., 2007. High-resolution U-series dates from the Sima de los Huesos hominids yields 600 kyrs: implications for the evolution of the early Neanderthal lineage. J. Archaeol. Sci. 34, 763-770.

Bookstein, F.L., 1989. Principal warps: thin-plate splines and the decomposiion of deformations. IEEE T. Pattern Anal. 11, 567-585

Bookstein, F.L., 1991. Morphomewic Tools for Landmark Data. Cambridge University Press, Cambridge

Bookstein, F.L., 1996a. Combining the tools of geomewic morphomewics. In: Marcus, L.F., Corti, M., Loy, A., Naylor, G.J.P., Slice, D. (Eds.), Advances in Morphomerics. Plenum Press, New York, pp. 131-151.

Bookstein, F.L., 1996b. Applying landmark methods to biological outline data. In: Mardia, K.V., Gill, C.A., Dryden, I.L. (Eds.), Inage Fusion and Shape Variability Techniques. Leeds University Press, Leeds.

Bookstein, F.L., 1997. Landmark methods for fonns without landmarks: morphome rics of group differences in outline shape. Med. Inage Anal. 1, $225-243$.

Bookstein, F.L., Schäfer, K., Prossinger, H., Seidler, H., Fieder, M., Stringer, C., Weber, G.W., Arsuaga, J.L., Slice, D.E., Roblf, F.J., Recheis, W., Mariam, A.J., Marcus, L.F., 1999. Comparing frontal cranial profiles in archaic and modern Homo by morphomewic analysis. Anat. Rec. (New Anat.) 257, 217-224

Bookstein, F.L., Sampson, P.D., Connor, P.D., Sweissguth, A.P., 2012. Midline corpus callosum is a neuroanatomical focus of fetal alcohol damage. Anat. Rec. (New Anat.) 269, 162-174.

Bookstein, F.L., Gunz, P., Mitteroecker, P., Prossinger, H., Schaefer, K., Seidler, H., 2013. Cranial integration in Homo: singular warp analysis of the midsagittal plane in ontogeny and evolution. J. Hum. Evol. 44, 167-187.

Butler, P.M., 1963. Tooth morphology and primate evolution. In: Brothwell, D.L. (Ed.), Dental Anthropology. Symposium Publications Division, Pergamon Press, New York

Bytnar, J.A., Trinkaus, E., Falsetii, A.B., 1994. A dental comparison of Middle Paleolithic Near Eastern hominids. Am. J. Phys. Anthropol. 19, 63

Dablberg, A.A., 1971. Penewance and expressivity of dental waits. In: Dablberg, A.A. (Ed.), Dental Morphology and Evolution. The University of Chicago Press, Chicago, pp. 257-262.
Dubois, E., 1894. Pithecanthropus erectus: eine menschenaebnlich Uebergangsforn aus Java. Landsdrukerei, Batavia.

Dryden, I.L., Mardia, K.V., 1998. Statical Shape Analysis. Wiley, Chichester.

Foley, R., Lahr, M., 1997. Mode 3 technologies and the evolution of modern humans. Camb. Archaeol. J. 7, 3-36.

Frieß, M., 2003. An application of the relative warps analysis to problems in human paleontology - with notes on raw data quality. Image Anal. Stereol. $22,63-72$.

Gabunia, L.K., de Lumley, M.A., Vekua, A., Lordkipanidze, D., de Lumley, H., 2012. Découverte d'um nouvel hominidé a Dmanisi (Transcaucasie, Géorgie). C.R. Palevol. 1, 243-253.

Gharaibeh, W., 2005. Correcting for the effect of orientation in geomeric morphome ric studies of side-view images of human heads. In: Slice, D.E. (Ed.), Modern Morphomewics in Physical Anthropology. Kuwer Academic/Plenum Publishers, New York, pp. 117-143.

González, V.M., 1990. Estudio de la dentición mandibular en la población hispano musulmana de San Nicolás (Murcia). Ph.D. Dissertation, Universidad Autónoma de Madrid.

Goose, D.H., 1963. Dental measurement: an assessment of its value in anthropological studies. In: Brothwell, D.R. (Ed.), Dental Anthropology. Pergamon, New York, pp. 125-148.

Groves, C.P., Mazák, V., 1975. An approach to the taxonomy of the Hominidae: gracile Villafranchian hominids of Africa. Casopis Min. Geol. 24, 225-247.

Griineberg, H., 1952. Genetical studies on the skeleton of the mouse. IV. Quasi-continuous variations. J. Genet. 51, 95-114.

Gunz, P., Mitteroecker, P., Bookstein, F.L., 2005. Semilandmarks in three dimensions. In: Slice, D. (Ed.), Modern Morphomewics in Physical Anthropology. Kluwer Academic/Plenum Publishers, New York, pp. 73-98.

Harvati, K., 2003. First Neanderthal remains from Greece: the evidence from Lakonis. J. Hum. Evol. 45, 465-473.

Hillson, S., 1986. Teeth. Cambridge University Press, Cambridge

Hillson, S., FitzGerald, C., Flinn, H., 2005. Alternative dental measurements: proposals and relationships with other measurements. Am. J. Phys. Anthropol. $126,413-426$

Hilusko, L.J., 2014. Protostylid variation in Australopithecus. J. Hum. Evol. 46, 579-594.

Hublin, J.J., 1982. Les ante néandertaliens: présapiens our prénéandertaliens? Géobios. Mem. Spec. 6, 345-357.

Hublin, J.J., 1984. The fossil man from Salzgitter-Lebenstedt (FRG) and its place in the human evolution during the Pleistocene in Europe. Z. Morphol. Anthropol. 75, 45-56.

Hublin, J.J., 1996. The first Europeans. Archaeology 49, 36-44

Hublin, J.J., 2001. Northwestern African Middle Pleistocene hominids and their bearing on the emergence of Homo sapiens. In: Barham, L., Robson-Brown, K. (Eds.), Human Roots: Africa and Asia in the Middle Pleistocene. Western Academic and Specialist Press, Bristol, pp. 99-121

Hylander, W.L., Johnson, K.R., 1992. Swain gradients in the craniofacial region of primates. In: Davidovitch, Z. (Ed.), The Biological Mechanism of Tooth Movement and Craniofacial Adaptation. Ohio State University College of Dentistry, Columbus, Obio, pp. 559-569.

Irish, J.D., 1993. Biological affinities of Late Pleistocene through modern African aboriginal populations: the dental evidence. Ph.D. Dissertation, Arizona State University.

Irish, J.D., 1997. Characteristic high- and low-frequency dental waits in subSaharan African populations. Am. J. Phys. Anthropol. 102, 455-467.

Irish, J.D., 1998. Ancestral dental waits in recent sub-Saharan Africans and the origins of modern humans. J. Hum. Evol. 34, 81-98

Irish, J.D., Guatelli-Steinberg, D., 2003. Ancient teeth and modern human origins: an expanded comparison of African Plio-Pleistocene and recent world dental samples. J. Hum. Evol. 45, 113-144.

Klein, R.G., 1999. The Human Career. University of Chicago Press, Chicago.

Labr, M., Foley, R., 1998. Towards a theory of modern human origins: geography, demography, and diversity in recent human evolution. Yearb. Phys. Anthropol. 41, 137-176.

Lalueza, C., Pérez-Pérez, A., 1993. The diet of the Neanderthal Child Gibraltar 2 (Devil's Tower) through the study of the vestibular striation pattern. J. Hum. Evol. 24, 29-41. 
Larsen, C.S., Kelley, M.A., 1991. In roduction. In: Kelley, M.A., Larsen, C.S. (Eds.), Advances in Dental Antbropology. Wiley-Liss, New York, pp. $1-5$.

Le Gros Clark, W.E., 195. Hominid characters of the Auswalopithecine dentition. J. R. Anthropo1. Inst. Gr. Brit. Ir. 81, 37-54.

Lozano, M., Bermúdez de Castro, J.M., Martinón-Torres, M., Sanniento, S., 2004. Cutmarks on fossil human anterior teeth of the Sima de los Huesos Site (Atapuerca, Spain). J. Archaeol. Sci. 31, 1127-1135.

Mantel, N.A., 1967. The detection of disease clustering and a generalized regression approach. Cancer Res. 27, 209-220.

Mardia, K.V., Kent, J.T., Bibby, J.M., 1979. Mulivariate Analysis. Academic Press, London.

Marinón-Torres, M., 2006. Evolución del aparato dental en homínidos: Estudio de los dientes humanos del Pleistoceno de la Sierra de Atapuerca (Burgos). Ph.D. Dissertation, Santiago de Compostela University.

Marinón-Torres, M., Bastir, M., Bermúdez de Castro, J.M., Gómez, A., Sanniento, S., Muela, A., Arsuaga, J.L., 2006. Homininlower second premolar morphology: evolutionary inferences through geometric morphometric analysis. J. Hum. Evol. 50, 523-533.

Mayhall, J.T., 2006. Dental morphology: techniques and strategies. In: Katzenberg, M.A., Saunders, S.R. (Eds.), Biological Anthropology of the Human Skeleton. Wiley-Liss, New York, pp. 103-134.

Mitteroecker, P., Gunz, P., Bernhard, M., Schaefer, K., Bookstein, F.L., 2004 Comparison of cranial ontogene jectories among great apes and humans. J. Hum. Evol. 46, 679-698.

Mitteroecker, P., Gunz, P., Bookstein, F.L., 2005. Heterochrony and geomeric morphometrics: a comparison of cranial growth in $P$ an paniscus versus Pan troglodytes. Evol. Dev. 7, 244-258.

Molnar, S., 1971. Human tooth wear, tooth function and cultural variability Am. J. Phys. Antbropol. 34, 175-190.

Morris, D.H., 1986. Maxillary molar occlusal polygons in five human samples. Am. J. Phys. Anthropol. 70, 333-338.

Nolte, A.W., Sheets, H.D., 2005. Shape base assignment tests suggest transgressive phenotypes in natural sculpin hybrids (Teleostei, Scorpaenifornes, Cotridae). Front. Zoo1. 2, 11

O'Connor, C.F., Franciscus, R.G., Holton, N.E., 2004. Bite force production capability and efficiency in Neandertals and modern humans. Am. J. Phys. Antbropol. 127, 129-151

O'Higgins, P., 2000. The study of morphological variation in the hominid fossil record: biology, landmarks and geomery. J. Anat. 197, 103-12

Pérez, S.I., Bernal, V., Gonzalez, P.N., 2006. Differences between sliding semi-landmark methods in geomeric morphomerics, with an application to human craniofacial and dental variation. J. Anat. 208, 769-784.

Pérez-Pérez, A., Espurz, V., Bennúdez de Castro, J.M., de Lumley, M.A., Turbón, D., 203. Non-occlusal dental microwear variability in a sample of Middle and Late Pleistocene human populations from Europe and the Near East. J. Hum. Evol. 44, 497-513.

Rak, Y., 1986. The Neandertal: a new look at an old face. J. Hum. Evol. 15, 151-164.

Rightmire, G.P., 1998. Human evolution in the Middle Pleistocene: the role of Homo heidelbergensis. Evol. Anthropol. 6, 218-227.

Roblf, F.J., 1996. Morphometric spaces, shape components and the effects of linear ransfornations. In: Marcus, L.F. (Ed.), Advances in Morphometrics. Plenum Press, New York, pp. 117-128.

Roblf, F.J., 1998a. TpsRelw. Ecology and Evolution. SUNY, Stony Brook, New York. Available online at: http://life.biosunysbedu/morph/.

Roblf, F., 1998b. TpsRegr. Ecology and Evolution. SUNY, Stony Brook, New York. Available online at: http://life.bio.sunysb.edu/morph/.

Roblf, F., 1998c. TpsDig. Ecology and Evolution. SUNY, Stony Brook, New York. Available online at: http://life.bio.sumysbedu/morph/.

Roblf, F., 1998d. TpsPLS. Ecology and Evolution. SUNY, Stony Brook, New York. Available online at: http://life.bio.sumysbedu/morph/.

Roblf, F., 1998e. TpsUtil. Ecology and Evolution. SUNY, Stony Brook, New York. Available online at: http://life.bio.sumysbedu/morph/.

Roblf, F.J., 2003. Bias and error in estimates of mean shape in geomeric morphomerics. J. Hum. Evo1. 44, 665-683.

Roblf, F.J., Marcus, L.F., 1993. A revolution in morphometrics. Tree 8-4, $129-132$
Roblf, F.J., Slice, D., 1990. Extensions of the Procrustes method for the optimal superimposition of landmarks. Syst. Zool. 39, 4-59.

Scott, G.R., Tumer II, C.G., 1997. The Antbropology of Modern Human Teeth: Dental Morphology and its Variation in Recent Human Populations. Cambridge University Press, Cambridge.

Sheets, H.D., 201. Inp, Integrate Morphome Package. Available online at: http://www.canisius.edu/ sheets/morphsoft.html.

Sheets, D.H., Kim, K., Mitchel, C.E., 2004. A combined landmark and outline-base approach to ontogenetic shape change in the Ordovician wilobite Triarthrus becki. In: Elewa, A. (Ed.), Morphomerics. Applicawons in Biology and Paleontology. Springer-Verlag, Berlin Heidelberg, pp. $67-82$

Slice, D., 201. Landmark coordinates aligned by Procrustes analysis do not lie in Kendall's shape space. Syst. Biol. 50, 141-149.

Smith, F., 1976. The Neandertal remains from Krapina. Univ. Tenn. Dept. Antbropol. Rep. Invest. 15, 1-359.

Sneath, P.H.A., 1967. Trend-surface analysis of transfornatrion grids. J. Zool. $151,65-122$

Stojanowski, C.M., 2007. Comment on "Alternative dental measurements" by Hillson, et al. Am. J. Phys. Antbropo1. 132, 234-237.

Swinger, C.B., 1984. The definition of Homo erectus and the existence of the species in African and Europe. Cour. Forsch. Inst. Senckenb. 69, 131-143.

Swinger, C.B., 1985. Middle Pleistocene hominid variability and the origin of Late Pleistocene humans. In: Delson, E. (Ed.), Ancestors: The Hard Evidence. Alan R. Liss, New York, pp. 289-296.

Swinger, C.B., 1993. Secrets of the pit of the bones. Nature 362, 51-502.

Swinger, C., 2002. Modern human origins: progress and prospects. Philos. Trans. R. Soc. London Ser B 357, 563-579.

Swinger, C., Hublin, J.J., 1999. New age es timates for the Swanscombe hominid, and their significance for human evolution. J. Hum. Evo1. 37, 873-877.

Tattersall, I., Schwartz, J.H., 1999. Hominids an hybrids: the place of Neanderthals in human evolution. Proc. Natl. Acad. Sci. 96, 7117-7119.

Thomason, J., 1997. Functional Morphology in Vertebrate Paleontology. Cambridge University Press, Cambridge.

Tobias, P.V., 1991. Olduvai Gorge. The skulls endocasts and teeth of Homo habilis. In: Parts V-LX, vo1. 4. Cambridge University Press, Cambridge.

Trinkaus, E., 1978. Bilateral asymme of human skeletal nonme ric Am. J. Phys. Anthropol. 49, 315-318.

Turner II, C.G., 1969. Microevolutionary interpretations from the dentition. Am. J. Phys. Antbropol. 31, 421-426.

Turner II, C.G., Nichol, C.R., Scott, G.R., 1991. Scoring procedures for key morphological traits of the permanent dentition: the Arizona State University Dental anthropology system. In: Kelley, M., Larsen, C. (Eds.), Advances in Dental Anthropology. Wiley Liss, New York, pp. 13-31.

Waddington, C.H., 1957. The Strategy of the Genes. Allen and Unwin, London.

Walker, A., Leakey, R.E., 1993. The Nariokotome Homo erectus Skeleton. Harvard University Press, Cambridge

Weidenreich, F., 1937. The dention of Sinanthrop us pekinensis; a comparative odontography of the hominids. Palaeontol. Sin. New Ser. D. 1. The Geological Survey of China

Wolpoff, M.H., 1971. Meric Trends in Hominid Dental Evolution. Press of Case Western Reserve University, Cleveland

Wood, B.A., 1984. The origin of Homo erectus. Cour. Forsch. Inst. Senckenb. 69, 99-111.

Wood, B.A., Abbott, S.A., Graham, S.H., 1983. Analysis of the dental morphology of Plio-Pleistocene hominids: II. Mandibular molars-study of cusp areas, fissure pattern and cross sectional shape of the crown. J. Anat. 137, 287-314.

Wood, B.A., Engleman, C.A., 1988. Analysis of the dental morphology of Plio-Pleistocene hominids: V. Maxillary postcanine tooth morphology. J. Anat. 161, 1-35.

Wood, B.A., Uytterschaut, H., 1987. Analysis of the dental morphology of Plio-Pleistocene hominids: III. Mandibular premolar crowns. J. Anat. 154, 121-156

Zelditch, M.L., Swiderski, D.L., Sheets, H.D., Fink, W.L., 2004. Geometric Morphomerics for Biologists: A Primer. Elsevier Academic Press, San Diego. 